\title{
Acetaminophen to reduce postoperative nausea and vomiting in patients undergoing strabismus surgery
}

\author{
Şaşıık ameliyatı geçiren hastalarda postoperatif bulantı ve kusmayı azaltmak için \\ asetaminofen
}

\section{(1) Lucas J CASTRO ALVES, (1) Mark C KENDALL}

To the Editor,

We read with great interest the article of Aksoy et al. ${ }^{[1]}$ in a recent issue of the journal. The authors performed a prospective randomized study on 96 patients undergoing strabismus surgery and concluded that the preoperative administration of paracetamol reduces PONV incidence in children undergoing strabismus surgery. The authors should be commended for performing a study in an important topic (e.g. acute pain and PONV) in pediatric patients undergoing surgery. ${ }^{[2,3]}$ The current emphasis on the need to use non opioid strategies to improve postoperative pain, nausea and vomiting makes the topic very relevant in perioperative medicine..$^{[4,5]}$

Although the study of Aksoy et al. was well designed and conducted, there are some concerns regarding the study that need to be clarified. First, the authors did not use any agent for PONV prophylaxis. The use of dexamethasone and ondansetron is common clinical practice after it has been recommended by practice guidelines. ${ }^{[6]}$ Secondly, the author have evaluated 15 outcomes on a three group design, but they did not correct their analysis to avoid type I errors. Lastly, the authors defined retching as nausea, but retching is frequently used as an aggregate of vomiting outcome in the literature.
We would welcome some comments to address the aforementioned issues as they were not discussed by the authors. This would help to further validate the findings of this important study.

\section{References}

1. Aksoy M, İnce I, Ahıskalıoğlu A, Keleş S, Doymuş Ö. Effect of intravenous preoperative versus postoperative paracetamol on postoperative nausea and vomiting in patients undergoing strabismus surgery: A prospective randomized study. Agri 2018;30(1):1-7. [CrossRef]

2. Shah RD, Suresh $\mathrm{S}$. Acute pain management in the pediatric ambulatory setting: How do we optimize the child's postoperative experience? J Clin Anesth 2017;40:103-4.

3. Turaç A, Rumeli Atıcı Ş. Evaluation of the effectiveness of patient-controlled analgesia in children with sickle cell anemia from the perspective of healthcare professionals and parents. [Article in Turkish]. Agri 2016;28(3):150-4.

4. Zhang Z, Xu H, Zhang Y, Li W, Yang Y, Han T, et al. Nonsteroidal anti-inflammatory drugs for postoperative pain control after lumbar spine surgery: A meta-analysis of randomized controlled trials. J Clin Anesth 2017;43:84-9. [CrossRef]

5. Li XD, Han C, Yu WL. Is gabapentin effective and safe in open hysterectomy? A PRISMA compliant meta-analysis of randomized controlled trials. J Clin Anesth 2017;41:76-83.

6. Gan TJ, Diemunsch P, Habib AS, Kovac A, Kranke P, Meyer TA, et al; Society for Ambulatory Anesthesia. Consensus guidelines for the management of postoperative nausea and vomiting. Anesth Analg 2014;118(1):85-113. [CrossRef]

\footnotetext{
Department of Anesthesiology, Rhode Island Hospital, The Warren Alpert Medical School of Brown University, Providence, Rhode Island, USA

Submitted (Başvuru tarihi) 15.03.2018 Accepted after revision (Düzeltme sonrası kabul tarihi) 11.09.2018 Available online date (Online yayımlanma tarihi) 08.04.2019 Correspondence:Dr.MarkCKendall.DepartmentofAnesthesiology,RhodelslandHospital,TheWarrenAlpertMedicalSchoolofBrownUniversity,Providence,Rhodelsland,USA. Phone: +90 - 401 - 4444933 e-mail: mark.kendall@lifespan.org

○ 2019 Turkish Society of Algology
} 